\title{
Ekspertens brod, den intellektuelles død? \\ Politik, viden og teknologi under den nukleare revolution
}

\author{
Rens van Munster \\ Seniorforsker, Dansk Institut for Internationale Studier (DIIS) \\ Casper Sylvest \\ Lektor, Institut for Historie, Syddansk Universitet (SDU)*
}

Er der forskel på „en ekspert“ og „en intellektuel"? Hvilken rolle tillægges eksperten og den intellektuelle i den offentlige debat - og hvilken rolle bør de tillægges? Dette er centrale spørgsmål i dag, hvor der er stor politisk efterspørgsel efter ekspertudsagn, mens den intellektuelle efterhånden har trange kår. I hvert fald ifølge Casper Sylvest og Rens van Munster. I et historisk studie af tiden kort efter opfindelsen af atom- og brintbomben viser de, hvordan intellektuelle, som stod udenfor det etablerede akademi, satte gang i kritiske offentlige debatter om moral og nye teknologier.

\section{Introduktion}

Et anerkendt historisk værk fra 1973 om Frankfurterskolens oprindelse og tidlige udvikling indledes med følgende udsagn: „Det er blevet almindeligt i den moderne verden at opfatte den intellektuelle som fremmedgjort, utilpasset og misfornøjet“" (Jay, 1973, 1). Fyrre år senere er der fortsat noget om snakken. I løbet af det 20. århundrede forandredes "den videndes" rolle i politik betydeligt. Årsagerne hertil skal findes i en bredere samfundsmæssig udvikling, der ikke begrænser sig til karakteren af den offentlige debat eller politisk kommunikation - de faktorer er selvsagt vigtige, men de er indlejret i nogle større historiske tendenser, der også indbefatter omfattende teknologiske og vidensøkonomiske forandringer.

I denne artikel stiller vi skarpt på den labyrintiske sammenhæng mellem viden og politik, som den udfoldede sig under den nukleare revolution. Termen anvendes her som en samlebetegnelse for de omfattende politiske og samfundsmæssige nybrud særligt i international politik og militær strategi som opfindelsen af atom- og siden brintbomben medførte i perioden fra ca. 1945-1965. Ikke mindst, vil vi hævde, havde særligt revolutionens anden fase en betydelig effekt på, hvordan politisk relevant viden blev opfattet, hvem der kunne hævdes at besidde troværdig viden, hvor den blev produceret, og hvordan den blev kommunikeret. ${ }^{1}$ Vores historiske analyse af de teknologiske, vidensøkonomiske og politiske forandringer under den nukleare revolution - og af modreaktioner og utilsigtede effekter - indeholder et normativt sigte og en politisk teoretisk udfordring. Der er naturligvis ingen nemme genveje eller læresætninger at finde i historien, men i undersøgelsen af den nukleare revolution får vi et særligt stærkt billede på et centralt paradoks i moderne politik; nemlig det forhold, at modernitetens intense samspil mellem viden, teknologi og politik i vid udstrækning er defineret ved specialiseret, problemløsende viden, mens samspillets effekter - i forhold til fx sikkerhedspolitik, klimaforandringer eller bioetik - fordrer en holistisk, normativ og kritisk analyse, der har svære kår i den aktuelle vidensøkonomi.

Analysen viser, hvordan vidensproduktion både blev militariseret og tættere knyttet til politisk autoritet under den nukleare revolution, hvilket havde en væsentlig betydning for den rolle, „den vidende“ kunne spille i politik. Perioden er, hævder vi, særligt vigtig for at forstå et skifte i idealbillede og politisk indflydelse væk fra „den intellektuell“" og i retning af „eksperten“. Lad det være sagt med det samme: Der var (og er) naturligvis modtendenser. En stor del af periodens måske væsentligste dissekering og kritik af den nukleare revolution og dens konsekvenser fandt imidlertid sted i marginen af eller endog uden for den etablerede og institutionaliserede viden(skab)sproduktion. Vi peger i denne sammenhæng på en gruppe af tænkere (som vi kalder nukleare realister), for hvem den nukleare revolution også fungerede som katalysator for nye, globale politiske visioner, der rakte ud over og søgte at underminere det ideologiske rationale bag natio- 
nal sikkerhed og opbygningen af det militær-industrielle kompleks særligt i USA. Artiklen indledes med en kort historisk skitse af forholdet mellem viden (eller rettere den vidende) og politik, hvorefter vi beskriver nogle generelle tendenser $\mathrm{i}$ henholdsvis natur- og samfundsvidenskaben (primært i USA) i efterkrigstiden første årtier. Dernæst vender vi os mod analysen af den gruppe af nukleare realister, som granskede, hvad rationalitet kunne og burde betyde efter den nukleare revolution, og for hvem politik i al væsentlighed blev forbundet med behovet for kritik, holistisk analyse og en fantasifuld forestillingsevne.

\section{Den intellektuelle fordring}

Begrebet „intellektuel“ er notorisk uklart, fordi det kan henvise til både kognitive evner og kulturelle roller (Allen, 1986). Derudover er det en kategori, der har udviklet sig i samspil med nogle bredere vidensøkonomiske tendenser i det 20. århundrede. Med en næsten håbløs generalisering kan man pege på, at den stigende specialisering af viden og den politiske relevans af specialiseret viden for politisk, primært statslig, autoritet har medført en forandring i den intellektuelles rolle. Hvor mange veluddannede med indkomster genereret ved videnskabeligt arbejde eller i ånds- og kulturlivet tidligere stræbte efter (at udtrykke sig med) visdom af filosofisk eller normativ karakter i sociale og politiske sammenhænge, er bevægelsen særligt i det 20. århundrede gået i retning af mere faktuelt orienteret viden baseret på konkrete kompetencer eller undersøgelser. Selvom „den intellektuelle“ aldrig har været synonymt med hverken „the sage“ eller "the expert", er begrebet blevet nært knyttet til en fremmedgjort inkarnation af førstnævnte, hvorimod sidstnævnte er det, der i stigende grad efterspørges politisk. Den intellektuelle er kritisk og afsondret; eksperten er politisk neutral og bidrager positivt til den politiske proces.

Der er naturligvis mange (lysende) eksempler på det modsatte, og der er tale om en gradvis udvikling. Den generelle trend synes dog svær at komme uden om, og den har grundlæggende indebåret en forandring i den rolle, som den vidende spiller i politik. Der har længe, mest ikonisk hos Platon, været fremført argumenter for at den vidende burde have betydende politisk magt, men med demokratiets konsolidering som politisk styreform og med den teknologiske udvikling, der karakteriserer det (sen)moderne, er det mindre som politisk leder end som rådgiver og bureaukrat (ja ligefrem teknokrat), at den vidende og veluddannede har udøvet magt. Det er dog sket inden for rammerne af en ekspertafhængig snarere end en filosofstyret politisk autoritet. Ikke desto mindre er det klart, at der i ekspertrollen ligger en massiv, om end ofte indirekte, skjult, strukturel, eller på anden vis udflydende politisk magt.
På mange politikområder har tilvejebringelse af videnskabelig viden om samfundsmæssige problemer haft positive effekter. Men på andre områder har det ført til selvransagelse og debat om den videndes rolle. Allerede i 1920erne påpegede franske Julien Benda, hvordan en tid domineret af passionerede politiske ideologier havde produceret en kaste af administrative eksperter og ledt øvige lærde til et forræderi, der bestod i en udsondring af den universelle, civiliserede fornuft til fordel for en forherligelse af irrationelle fænomener som racisme og nationalisme (Benda, 2009). Særligt spørgsmålet om organiseret voldsanvendelse kom til at stå centralt i denne debat. Allerede under første verdenskrig stod det klart, at videnskabsmænd (der primært var mænd), såvel som arbejdere, følte sig nært knyttet til fædrelandet (se fx Sylvest 2009). Skuffelsen var for mange proportional med de store forhåbninger, der siden oplysningstiden havde været knyttet til netop fornuftens evne til at udradere nationale konflikter og krig.

Samtidig var den fri produktion og udveksling af viden for universelle, apolitiske formål et ideal for mange, fx Max Weber. Ambitionerne på vegne af den værdifri videnskab var mere afmålte, men idealet havde stadig betydelig appel. Bendas universelle intellektuelle hørte nok en svunden tid til, men den værdifri, specialiserede ekspert kunne måske overleve? Også det ideal blev dog skudt i sænk i løbet af det 20. århundrede. Videnskabelig viden og dens teknologiske frembringelser spillede nemlig en afgørende rolle for det ragnarok af krig og masseudryddelse, der udspillede sig. Det ligner en blindgyde:
Attempts at intellectual purity in the modern world have a tendency to collapse into their opposite. Weber's defence of intellectual integrity as value-neutrality has the paradoxi- cal effect of allowing the intellectual to become an instrument or resource for the state. And the price of ethical purity for Benda's clerk is ceding the world to Caesar and to Machtpolitik. Efforts to hold the realm of knowledge apart from the realm of power appear doomed to failure (Thorpe 2004: 65).

Selvom alternativet ikke var problemfrit, blev det romantiske ideal om den universelle intellektuelles visdom i stigende grad fortrængt. Majoriteten af de vidende antog i stedet roller som specialister eller eksperter. Deres opdrag var kort sagt at bidrage til den politiske proces med deres ekspertise. Det medførte ikke kun en stærkere statslig styring, men også øget magt til eksperten: Politiske magthavere, $\mathrm{fx}$ den amerikanske præsident Dwight D. Eisenhower, frygtede ligefrem, at offentlige anlig- 
gender (og dermed også store dele af videnskaben) ville blive udnyttet af det militær-industrielle kompleks, som han beskrev og advarede imod i sin berømte afskedstale til den amerikanske nation i januar 1961. Anledningen hertil var meget konkret og stærkt forbundet med udviklingen i den amerikanske kernevåbenpolitik; det var den ungarsk-fødte amerikanske videnskabsmand Edward Tellers heftige agitation for udviklingen af brintbomben, der angiveligt gav Eisenhower ideen til hans afskedstale (Rubinson, 2011, 306).

Eisenhower havde god grund til at være bekymret, for siden anden verdenskrig var sammenkoblingen mellem videnskaben og sikkerhedspolitikken blevet stadig mere intens. Forskere har i den sammenhæng beskrevet, hvordan en afgørende faktor $i$ institutionaliseringen og professionaliseringen af universitetssystemet i USA var et produkt af et imperativ om national sikkerhed (Chomsky, 1997; Lowen, 1997; se også Engerman, 2003). Bag dette „Koldkrigs-universitet“ lå en dobbelt påvirkning. På den ene side blev meget forskning finansieret af militæret og CIA, hvilket øvede indflydelse på valg af forskningsobjekter. Men militæret havde også en mere vidtrækkende strukturel betydning. Finansieringen af nye tværdisciplinære områder såsom cybernetics, rational choice, behavioral science og lignende fordrede en bestemt politisk og kulturel verdensanskuelse på tværs af discipliner og individuelle forskere (Kuklick, 2006; Mirowski, 2012):

[A] new approach to democracy emerged in Cold War America, one based on the notion of the 'rational actor,' which was quickly assimilated into traditions of political and economic liberalism that underlie the modern experiment with democracy and capitalism ... The set-theoretic and axiomatic treatment of human rationality came to serve as the new standard for describing the zenith of human consciousness, and could be used as a virtual litmus test to determine if one were a liberal individualist or an irrational collectivist (Amadae, 2003, 3).

For videnskabsmænd var det i stigende grad besværligt at indtage positioner, der udfordrede de dominerende værdier og antagelser, der i sig selv fremstod neutrale og eftertragtelsesværdige. Den universelle intellektuelles ambition blev gradvist sidestillet med en kritisk, oppositionel (til tider endda kommunistisk) tendens, hvilket næsten per automatik medførte en fremmedgørelse over for det etablerede politiske system. Det primære formål for den universelle intellektuelle var netop ikke at servicere den politiske proces med ekspertise, men at dissekere betin- gelserne for det politiske i en moderne verden. Det ledte nødvendigvis til en mere marginaliseret tilværelse, og det er med til at forklare, hvorfor den intellektuelle, som Jay beskriver det, blev en „fremmedgjort, utilpasset og misfornøjet" skikkelse.

\section{Naturvidenskabernes forandring}

"I have become Death, the destroyer of Worlds“. Med disse ord fra Bhagvad Gita gav den civile leder af Manhattan projektet, Robert J. Oppenheimer, efter Trinity testen i 1945 udtryk for sin moralske sindsoprivelse ved det produkt, han havde været med til at frembringe. For Michel Foucault (2001) symboliserer Oppenheimer skiftet fra den universelle intellektuelle til ekspertrollen. Det var netop Oppenheimers privilegerede ekspertposition som atomfysiker og leder af Manhattan projektet, der muliggjorde, at han kunne udtale sig med en stor legitimitet om bombens globale effekter. Oppenheimer var dog langt fra alene. For mange videnskabelige kollegaer som Einstein, Fermi og Bohr, blev bomben begyndelsen på en moralsk animeret fredsaktivisme med det formål at bringe bomben under international eller supranational kontrol. Amerikanske naturvidenskabsmænd og deres allierede (fx United World Federalists) brugte deres specialiserede viden om det nye våben som platform for et moralsk og politisk projekt, der resonerede med store dele af den amerikanske befolkning. Ambitionen blev udtryk i sloganet „One World or None“, der oprindeligt var titlen på en populær pamflet (Masters and Way, 1946), men som hurtigt blev et samlende motto for en hel bevægelse og dens kampagne for supranational kontrol over bomben.

Selvfølgelig delte ikke alle naturvidenskabsmænd bevægelsens opfattelse af, at valget stod mellem katastrofe eller overdragelse af suverænitet. Måske særligt for Edward Teller - men også for andre - var atom- og (senere) brintbomben et nødvendigt og anvendeligt instrument $i$ en episk, politisk konflikt mellem den frie verden og kommunismen. ${ }^{2}$ Fælles for videnskabsmændene var dog, at atomvåben blev diskuteret i moralske og politiske termer. En væsentlig grund til, at især fredsaktivisterne blev særligt populære og indflydelsesrige i de første år efter krigen var, at USA fortsat besad et monopol på atomvåben, og at den Kolde Krig endnu ikke havde nået frysepunktet. International kontrol var derfor stadig en realistisk mulighed (Wittner, 2009); på baggrund af store dele af den videnskabelige autoritets dystopiske forudsigelser blev den nærmest set som en nødvendighed (Boyer, 1985).

En hang til eksistentiel filosofi og kritisk refleksion blev dog i stigende grad problematisk i et samfund, der, efter at Sovjetunionen blev en atommagt i 1949, afsatte enorme ressourcer til den forestående kamp. Ideen om, at atomvåben kunne underlægges supranational kontrol, 
var stadig beundringsværdig som aspiration, men i offentligheden fremstod den tonedøv i mødet med stormagtspolitikkens logik. Udfaldet af Oppenheimers berygtede sikkerhedshøring i 1954, hvor den tidligere så feterede videnskabsmand mistede sin sikkerhedsgodkendelse og blev afklædt offentligt, kom til at stå som symbolet på denne udvikling. Den var en advarsel til andre videnskabskvinder og -mænd: det nye politiske klimas tolerance over for moralske kvaler var begrænset. Den amerikanske atomenergikommissions endelige afgørelse i sagen gjorde det klart, at '[e]motional involvement in the current crisis, like all other things, must yield to the security of the nation'. ${ }^{3}$

I en sådan situation blev det stadig mere vanskeligt at kritisere det voksende amerikanske kernevåbenkompleks - og dets underliggende rationale, værdier og trusselsbillede - med moralske argumenter uden samtidig at miste politisk anseelse og indflydelse. Det betød ikke, at naturvidenskabsmænd havde udspillet deres rolle. Videnskaben nød fortsat stor anseelse, men den rolle videnskabsmænd kunne spille i politik, herunder kernevåbenpolitik, forandredes. Hvor Oppenheimer kunne mobilisere sin viden til at fremme en global dagsorden, viser Paul Rubinson (2011), at ekspertise siden hen i stigende grad baseredes på en grundlæggende accept af en række eksisterende politiske forhold - bl.a. afskrækkelseslogikken - der dominerede verdensforståelsen i USA. En sådan bevægelse kan særligt spores blandt regeringsansatte videnskabsmænd, men den påvirkede også transnationale bevægelser såsom Pugwash, der opererede uafhængigt. ${ }^{4}$ Deres rolle forandredes i retning af den teknisk-videnskabelige ekspert, hvis konklusioner politikere og diplomater kunne inddrage i det politiske system. Moralsk uenighed mellem videnskabsmænd blev dermed afløst af konfligerende videnskabelige vurderinger, som politikere kunne bruge (og misbruge). ${ }^{5}$

\section{Samfundsvidenskabernes forandring}

Brugen af atomvåben mod Hiroshima og Nagasaki påvirkede ikke kun naturvidenskaben. I samfundsvidenskaben ledte bomben til spørgsmål om, hvordan man nu skulle forstå krig og politik? En fremtrædende opfattelse blandt samfundsvidenskabelige forskere var, at mennesket (og dermed samfundsvidenskaben) haltede langt efter teknologien (og dermed naturvidenskaben). Hvor sidstnævnte havde frigjort naturens mest elementære kræfter, var samfundsvidenskaben endnu ikke klar med et svar på bombens konsekvenser. Ideen om en sådan kløft kom oprindeligt fra sociologen William F. Ogburn, men blev i 1940'erne allemandseje i samfundsvidenskabens forsøg på at slå bro mellem social man og scientific man. ${ }^{6}$ Samfundsvidenskab kunne (og burde) i den sammenhæng spille en væsentlig rolle i udtænkningen af løsninger, fx i forhold til udnyttelsen af atomenergi eller i forståelsen og kortlægningen af fremmede samfund. ${ }^{7}$ Hvor naturvidenskabsmændene oprindeligt valgte en aktivistisk tilgang, påtog samfundsvidenskabelige forskere sig altså i høj grad rollen som ekspert eller social engineer.

Et relevant eksempel i denne sammenhæng er politologen Bernard Brodie, der også tog udgangspunkt i ideen om en kløft (eller et "lag“) mellem naturvidenskabens frembringelser og samfundets efterfølgende tilpasning (Brodie, 1947: 32). Brodie opponerede mod naturvidenskabsmændenes brug af frygt som politisk kampagne, netop fordi det udtrykte en illusion: '[a]bsolute security against the atomic bomb lies irretrievably in the past, and neither panic nor incantations will help us to reinvoke it' (Brodie, 1947, 41). I stedet gav Brodie sig til at gentænke amerikansk militærstrategi som afskrækkelse, hvor målet ikke var at føre krig, men at forebygge den. Til dette formål lod han sig inspirere af økonomisk teori med argumentet om, at 'what is needed in the approach to strategic problems is genuine analytical method' (Brodie, 1949b, 484). Implikationen var ikke til at overse: samfundsvidenskabens ekspertise kunne guide amerikansk strategi. ${ }^{8}$ I mødet med det revolutionært nye trak Brodie på gamle tankemønstre (Kuklick, 2006, 58), men det medførte, at one world-logikken blev vendt på hovedet: 'Our problem now is to develop the habit of living with the atomic bomb, and the very incomprehensibility of the potential catastrophe inherent in it may well make that task easier' (Brodie, 1948: 33; Brodie, 1949a: 173). ${ }^{9}$

På trods af samfundsvidenskabens betydelige ambitioner om at matche naturvidenskaben vidner Brodies (og Ogburns) arbejde om begrænset kreativitet og refleksivitet. For selvom både Ogburn og Brodie forstod udviklingen af atombomben som en revolutionar begivenhed, var deres analyser af fx tilgængeligheden og anvendelsen af militær magt eller forholdet mellem teknologi og samfund efter bomben ret blodfattige. De beskæftigede sig ikke indgående med spørgsmål om politisk etik, demokrati, legitimitet og politisk autoritet eller de bredere individuelle, sociale eller miljømæssige konsekvenser af deres foreslåede strategier og planer - og denne tendens ændrede sig ikke, men blev måske ligefrem forstærket, med nye strukturer for forskningsfinansiering og regeringens stigende efterspørgsel på ekspertviden..$^{10}$ Sammenfattende kan man konkludere, at samfundsvidenskabens ambition om at bygge bro mellem natur og samfund - at lukke hullet til det teknologisk-naturvidenskabelige udbrud - begransede dybdeborende og refleksive analyser af den nukleare revolutions implikationer og udfordringer. 


\section{Et alternativ: nuklear realisme}

Rationalet bag denne bevidst samfundsvidenskabelige forskning (og måske særligt strategisk tænkning) blev genstand for omfattende kritik i 1960'erne, da populærkulturelle formidlinger som Stanley Kubricks Dr. Strangelove og politiske begivenheder som Vietnamkrigen tydeligjorde de menneskelige og økonomiske omkostninger af disse tilknappede „virkelighedsfantasier“ (se fx Engerman, 2003). 1960'erne fremstår dermed i dag som årtiet, hvor ungdom og nytænkning gjorde oprør mod ekspertvælde, kynisme, tradition og forældede tankemønstre. Selv det nye har dog en historie, og betydelige dele af de ideer og den kritik, der animerede ungdomsoprøret spirede allerede i 1950'erne (Jamieson og Eyerman, 1994). Der fandtes faktisk en kritisk analyse af kernevåben og deres sociale og politiske konsekvenser i 1950erne, men den blev overvejende fremført af (mere gammeldags universelle) intellektuelle som i udviklingen af særligt brintbomben identificerede et fundamentalt paradigmeskift.

Denne kritik af bomben som artefakt og institution ledte til en række radikale udfordringer og indsigter, der siden opnåede betydelig politisk appel og som - på visse områder - har betydelig relevans i dag. I dette afsnit illustrerer vi nogle væsentlige aspekter af denne oversete historie ved at sætte fokus på en gruppe af tænkere, vi betegner „nukleare realister“. Vi definerer „nuklear realisme" som en særlig tilgang til den nukleare revolution, der var baseret på en overbevisning om, at den liberale modernitet kun kunne afværge kollektivt selvmord ved at gentænke og nyordne sit fundament. Nuklear realisme er et transnationalt og interdisciplinært fænomen, der dog er bundet til en specifik tid (primært de to årtier efter opfindelsen af atombomben og særligt i perioden fra 19521963). I sit udtryk kombinerer denne form for tænkning både politisk teori og kulturkritik, mens den i indhold overlapper med (men ikke udtømmer) politisk realisme, som det i dag forstås i historisk og politologisk forskning.

Elementer af denne radikale dissekering af modernitetens nye betingelser kan findes hos mange intellektuelle i 1950'erne, men vi fokuserer særligt på fire tænkere, der både demonstrerer bredden og diversiteten i „nuklear realisme“, men som også har tilstrækkelige „familieligheder" til at de sammenhængende kan behandles under ét: Günther Anders (1902-1992), John H. Herz (1908-2005), Lewis Mumford (1895-1990) og Bertrand Russell (18721970). Det mest bemærkelsesværdige ved den nukleare realismes reaktion på atom- og brintbomben var, at den begyndte med en krads eksamination af militærmagtens forandrede natur og tilgængelighed. Mange andre - generaler, politikere og akademikere - havde peget på bombens revolutionære karakter, for derefter igen at vende sig mod pre-revolutionære tankesæt. Afskrækkelseslogikken var netop hentet fra klassisk militær tænkning, men blev så i løbet af 1950'erne installeret som det nye fundament for Vestens ageren i den Kolde krig. Nukleare realister begyndte altså fra en genkendelig præmis - „Der vil ikke være en vinder i tredje verdenskrig“, som Mumford (1954, 88) formulerede det - men de gennemførte en mere kritisk og skeptisk analyse af, hvad afskrækkelse indebar både rationelt, militært og moralsk. Særligt med udviklingen af brintbomben, der kunne produceres i variationer, der var op til 1000 gange kraftigere end de bomber, der blev brugt mod Japan i 1945, intensiveredes de nukleare realisters bekymringer og kritik.

Lewis Mumford havde allerede i 1946 proklameret, at atombombens opfindelse var en form for galskab (Mumford, 1946), der kun kunne finde sted, fordi de vestlige magter havde svigtet deres moralske fundament ved at tæppebombe civile under krigen. Samtidig blev han stadig mere optaget af den tilstand som truslen om den totale atomkrig indebar. Analogien til 2. verdenskrig var klar: at leve med truslen om atomkrig var at transformere byer, lande, ja hele verden til en mental koncentrationslejr. John Herz (1962: 124) pegede også på denne analogi mellem udryddelseslejren og det ultimative udryddelsesvåben. Men, kunne man indvende, det smukke ved afskrækkelseslogikken var jo netop, at man ved at true med anvendelsen af kernevåben kunne sikre sig, at de ikke blev anvendt. Givet de ganske betydelige risici ved den logik, tjener det de nukleare realister til ære, at de faktisk grundigt analyserede, hvad logikken indbefattede. Selvom nukleare realister generelt var skeptiske over for afskrækkelse og dens mange aspekter ${ }^{11}$, var det deres analyse af den underliggende rationalitet, der dybest set ledte dem til at forkaste logikken. Kernevåben var netop et udtryk for både den videnskabelige rationalitets triumf og menneskets politiske og moralske fallit. Med kernevåbnenes opfindelse havde mennesket mødt rationalitetens grænse, og hvad tilhængerne af afskrækkelse ikke så - ud over at de undervurderede strategiens risici - var, at kernevåben qua denne status ikke kunne håndteres med den rene rationalitet.

Troen på, at produktet af rationalitetens ultimative irrationalitet kunne håndteres rationelt blev imidlertid en form for offentlig hypnose, der samtidig gjorde samfundet blindt over for kernevåbnenes moralske aspekter. Bertrand Russell kom (delvist uintenderet) til at illustrere netop dette paradoks ved at sammenligne afskrækkelse med spillet „chicken“ - hvor to biler i høj fart kører mod hinanden for at afgøre, hvilken chauffør der er modigst - blot for at se sin idé misbrugt i Herman Kahn's On Thermonuclear War; en bog, Russell fandt overdrevent optimistisk og afstumpet i sit forsøg på rationelt at „gennemtænke det utænkelige“ (Russell, 1959; Russell, 1961). 
Lewis Mumford var dog nok den mest radikale kritiker af denne tankegang. Ved at besværge sig til en påstået videnskabelig rationalitet fabrikerede moderne strategisk tænkning en dødsfælde, og alligevel præsenterede den sig uanfægtet som hårdkogt realisme: 'How far can human self-deception go?', spurgte Mumford (2006: 15). En del af svaret fandt Mumford i den underkastelse af „maskinen“, som karakteriserede moderne samfund. „Maskinen“ var netop en pervertering af den videnskabelige rationalitet, der producerede en subtil men indgribende underkastelse - „et mekanisk konstrueret koma“ (Mumford, 1956: 174; se også Herz, 1962: 143):

As a nation we are now under the control of under-dimensioned minds with five-year perspectives, immune to humane concerns: indifferent alike to the rich historic past they would nullify or the endless potentialities of the future they would abort or sterilize. Such demoralized minds are capable in fantasy of wiping out sixty million of their fellow-countrymen, and congratulating themselves on contriving shelters that might save, also largely in fantasy, the bodies of some fraction of those that would remain. These Genghis Khans of strategy have conditioned their countrymen to ignore the fact that this unseemly massacre may still be avoided by adroit changes in military and political policy which a more humane intelligence could bring about. But in a world like ours, empty of historic values or purposes, the crassly optimistic reassurances of scientific fortunetellers are treated as oracles, while the well-grounded warnings of its humane Einsteins and Schweitzers and Russells are disregarded (Mumford, 1962: 213-214). ${ }^{12}$

Selvom der var forskelle mellem de nukleare realisters analyse af militær magt $\mathrm{i}$ atomalderen - og i intensiteten af deres kritik af afskrækkelsesdoktrinen - er det bemærkelsesværdigt, at de fra dette udgangspunkt blev ledt til en gennemgribende analyse af moderniteten. Det er fx særligt tydeligt i forhold til deres forsøg på at gentænke politisk autoritet uden for nationalstatens rammer, i deres analyse af teknologiens (fremmedgørende) indflydelse på det sociale liv ( $\mathrm{fx}$ i produktionen af konformitet og samtykke) eller i deres tidlige påpegning af globale miljøproblemer. Her ligger meget interessant tankegods, hvor den nukleare revolution blev det nybrud, der endegyldigt fordrede en gentænkning af betydningen af frihed, teknologi og hele det menneskelige liv.
Samtidigt var det også et opgør med betingelserne for intellektuel aktivitet i det hele taget. Nukleare realister var stærkt skeptiske over for „Koldkrigsuniversitet“ og det nukleare ekspertvælde. I stedet for at postulere en eksklusiv ret til at udtale sig som ekspert i nukleare våben forsøgte de netop at gøre det absolutte våben til genstand for en bredere offentlig debat: 'If the word „Democracy" has any sense at all, then it means that precisely the province beyond our professional competence should concern us', som Günther Anders (1962: 500) formulerede det. Deres selvopfattelse som intellektuelle pegede i samme retning. Anders afviste fx en akademisk karriere for at kunne mobilisere befolkningen igennem sine bøger. Bomben truer ikke kun universitetsbygningerne, som han sagde (Anders, 1956: 237). Russell, der igennem længere tid havde holdt lav profil som aktivist og arbejdet for tilvejebringelsen af videnskabelig information om konsekvenserne af kernevåben og atmosfæriske prøvesprængninger ( $\mathrm{fx}$ gennem etableringen af Pugwash), blev en førende fredsaktivistist i slutningen af 1950'erne og starten af 1960erne (Sylvest, 2014). Selv den mest „akademiske" blandt de her fremhævede nukleare realister, John Herz, kom til den konklusion, at det Weberianske ideal om en 'uncommitted, ivory-tower researcher' nu burde erstattes af ideen om 'homme engagé, if not homme révolté' (Herz, 1976b: 258).

For dem alle var katalysatoren i denne udvikling, at en nuklear katastrofe (og den menneskelige katastrofe det indebar at leve i et samfund, hvor muligheden for global selvdestruktion var konstant og realistisk) kun kunne afværges ved en større moralsk transformation, 'the increase of self-understanding, self-control, self-direction and self-transcendence' (Mumford, 1959c: 77). Selv om de var opmærksomme på, at de idealistiske løsninger, som naturvidenskabsmænd havde forsøgt sig med i 1940'erne, var endnu mere usandsynlige i 1950'erne, blev de aldrig trætte af at påpege nødvendigheden af alternative, mere fremsynede og kreative politiske løsninger end dem fx strategiske eksperter og åndsfrosne koldkrigere kunne tilbyde. Mumford formulerede det mest komprosmisløst, da han argumenterede imod det synspunkt, at politik i den nukleare alder bedst kunne beskrives som det muliges kunst: 'If politics means anything today, it must become „the art of the impossible." The people who sacrifice every principle to expediency, every long-range plan to immediate profit, are the people who live in a world of slippery fantasies and self-deceptions' (Mumford, 1954a: 7).

\section{Konklusion og perspektiver}

Som blandt andet det stigende antal tænketanke på en lang række områder vidner om, er ideen om den vidende som ekspert velaccepteret, mens den intellektuelle (eller 
værre: smagsdommeren) har sværere kår både i politik og i akademiet. Historien om natur- og samfundsvidenskabens forandring under den nukleare revolution peger dog på, at den „neutrale“ og rationelt frembragte ekspertviden har betydelige begrænsninger i forhold til vores måde(r) at tænke politik på. Det gælder også i forhold til aktuel atomvåbenpolitik, hvor et velfinansieret „ikkespredningskompleks" bestående af bl.a. ikke-statslige uddannelsesinstitutioner og tænketanke anklages for at have tilpasset sig stormagternes - og ikke mindst USA's - politiske interesser (Craig and Ruzicka, 2013).

Selvom den umiddelbare trussel om en nuklear krig er aftaget, og selvom nogle vidensinstitutioner i USA ikke er bundet op på militæret på samme måde eller i samme grad som under den Kolde Krig, skaber nye globale problemer, som klima eller teknologiske nybrud indenfor $\mathrm{fx}$ biogenetik, et fortsat behov for at gen(nem)tænke den menneskelige tilstand. Spørgsmålet er imidlertid i hvor høj grad kompartmentaliseret og specialiseret ekspertviden bidrager hertil. Natur- og samfundsvidenskabens status i den nukleare revolutions anden fase tegner et ret pessimistisk billede. Det er i hvert fald tankevækkende, at den mest fundamentale kritik af kernevåben og dens følger blev fremført af intellektuelle, der til dels stod uden for akademiet. Ligeledes er det bemærkelsesværdigt, at nukleare realister netop $i k k e$ var specialister, men derimod mente, at en bredere debat var en vigtig forudsætning for et velfungerende demokratisk samfund.

Den nukleare revolutions anden fase er selvfølgelig en ekstrem periode i forholdet mellem viden og politik. Men dens historie indeholder også aktuelle udfordringer. Den intellektuelles potentielle bidrag var (og er) primært samfundskritisk og debatskabende. For det første kan den intellektuelle bidrage med en variant af den form for kritisk forestillingsevne som C. Wright Mills beskrev i Den sociologiske fantasi (1959); en evne der indebærer at træde udenfor det gængse og accepterede og anskue problemer og vores forståelse af dem på nye måder. For det andet og mere konkret kan den „offentlige“ intellektuelle, der skriver til et bredt publikum og udfordrer den oftest indforståede „sunde fornuft", bidrage til nødvendige diskussioner om forhold, der rent faktisk vedrører os alle. I det lys er det relevant at spørge om der i dag er plads til et ikke-specialiseret intellektuelt engagement med globale sikkerhedsspørgsmål såsom klima og kernevåben, hvor vi kan forvente at et sådant engagement $i$ givet fald skal komme fra, og om vores etablerede vidensøkonomiske strukturer ikke i højere grad bør anspore det? Der er her tale om debatter, der ikke kun handler om fakta, men også om kreativitet, moral, kritik og holistisk tænkning. Det vedrører kort sagt, om vi stadig vil og kan forestille os verden anderledes end den er.

\section{Litteratur}

Allen, Peter (1986) 'The Meanings of „An Intellectual“: Nineteenthand Twentieth Century Usage', University of Toronto Quarterly, 55(4), 342-58.

Amadae, S.M. (2003) Rationalizing Capitalist Democracy. The Cold War Origins of Rational Choice Liberalism. Chicago: Chicago University Press.

Anders, Günther (1956) Die Antiquiertheit des Menschen: Über die Seele im Zeitalter der zweiten industriellen Revolution. Third edn. Munich: C.H. Beck.

-..-- (1962) 'Theses for The Atomic Age', Massachusetts Review, 3, 493505 .

Arendt, Hannah (1969) On Violence. Orlando: Harcourt, Inc.

Baldwin, David A. (1995) 'Security Studies and the End of the Cold War', World Politics, 48, 117-41.

Ball, Terrence (1989) 'The Politics of Social Science in Postwar America', in L. May (ed.), Recasting America: Culture and Politics in the Age of the Cold War. Chicago: University of Chicago Press, 76-92.

Benda, Julien (2009 [1927]) The Treason of the Intellectuals. New Brunswick: Transaction Publishers.

Boyer, Paul (1985) By the Bomb's Early Light: American Thought and Culture at the Dawn of the Atomic Age. New York: Pantheon.

Boyer, Paul (1998) Fallout. A Historian Reflects on America's Half-Century Encounter with Nuclear Weapons. Columbus: The Ohio State University Press.

Brodie, Bernard (1947) 'The Atomic Dilemma', The Annals of the American Academy of Political and Social Science, 249, 32-41.

Brodie, Bernard (1948) 'The Atom Bomb as Policy Maker', Foreign Affairs, 27(1), 17-33.

Brodie, Bernard (1949a) 'New Techniques of War and National Policies', in William Fielding Ogburn (ed.), Technology and International Relations. Chicago: Chicago University Press. 144-73.

Brodie, Bernard (1949b) 'Strategy as a Science', World Politics, 1(4), 467-488.

Chomsky, Noam et al. (1997) The Cold War \& The University: Toward an Intellectual History of the Postwar Years. New York: The New Press.

Craig, Campbell and Jan Ruzicka (2013) 'The Nonproliferation Complex', Ethics and International Affairs, 27, 329-48.

Edwards, Paul (1996) The Closed World. Computers and the Politics of Discourse in Cold War America. Cambridge: MIT Press.

Edwards, Paul N. (2012) 'Entangled Histories: Climate Science and Nuclear Weapons Research', Bulletin of the Atomic Scientists, 68, 28-40.

Egan, Michael (2007) Barry Commoner and the Science of Survival: The Remaking of American Environmentalism. Cambridge: MIT Press.

Engerman, David (2003) 'Rethinking Cold War Universities: Some Recent Histories', Journal of Cold War Studies, 5(3), 80-95.

Foucault, Michel (2001) 'Truth and Power', in Michel Foucault, Power. Essential Works of Foucault 1954-1984 (volume 3). Edited by James D. Faubion. London: Penguin, 111-133.

Gilman, Nils (2003) Mandarins of the Future: Modernization Theory in Cold War America. Baltimore: Johns Hopkins University Press.

Hamblin, Jacob Darwin (2013) Arming Mother Nature: The Birth of Catastrophic Environmentalism. Oxford: Oxford University Press.

Herz, John H. (1959) International Politics in the Atomic Age. New York: Columbia University Press.

Herz, John H. (1976a [1962]) 'International Politics and the Nuclear Dilemma', in John H. Herz, The Nation-State and World Politics. New York: McKay, 124-147.

Herz, John H. (1976b) 'Relevancies and Irrelevancies in the Study of International Relations', in John H. Herz, The Nation-State and World Politics. New York: McKay, 253-278. 
Jacobs, Robert A. (2010) 'Curing the Atomic Bomb Within: The Relationship of American Social Scientists to Nuclear Weapons in the Early Cold War', Peace and Change, 35(3), 434-463.

Jay, Martin (1973) The Dialectical Imagination: A History of the Frankfurt School and the Institute of Social Research, 1923-50. Boston: Little, Brown and Co.

Kuklick, Bruce (2006) Blind Oracles: Intellectuals and War from Kennan to Kissinger. Princeton: Princeton University Press.

Lewenstein, Bruce V. (1992) 'The meaning of 'public understanding of science' in the United States after World War II', Public Understanding of Science, 1, 45-68

Lowen, Rebecca S. (1997) Creating the Cold War University: The Transformation of Stanford. Berkeley: University of California Press.

Mandler, Peter (2012) 'Deconstructing Cold War Anthropology', in J. Isaac and D. Bell (eds) Uncertain Empire: American History and the Idea of the Cold War. Oxford: Oxford University Press, 245-266.

Masco, Joseph (2010) 'Bad Weather: On Planetary Crisis', Social Studies of Science, 40(1), 7-40.

Masters, Dexter and Katharine May (eds.) (1947 [1946]) One World or None. London: Latimer House.

Mills, C. Wright (2002 [1959]) Den sociologiske fantasi. København: Hans Reitzels Forlag.

Mirowski, Philip (2012) 'A History best Served Cold', in Duncan Bell and Joel Isaac (eds) Uncertain Empire: American History and the Idea of the Cold War. Oxford: Oxford University Press, 61-74.

Mumford, Lewis (1954) 'Alternatives to the H-Bomb', New Leader, 37, 4-9.

Mumford, Lewis (1956) The Transformation of Man. New York: Harper and Bros.

Mumford, Lewis (1959) 'The Moral Challenge to Democracy', Virginia Quarterly Review, 35, 560-76.

Mumford, Lewis (1962) 'An Apology to Henry Adams', Virginia Quarterly Review, 38, 196-217.

Mumford, Lewis (2006 [1958]) The Human Way Out. Wallingford, PA: Pendle Hill.

Ogburn, William Fielding (1946) 'Sociology and the Atom', The American Journal of Sociology, $\mathrm{LI}(4), 267-275$.

Rubinson, Paul (2011) '„Crucified on a Cross of Atoms“: Scientists, Politics and the Test Ban Treaty', Diplomatic History, 35(2), 283-319.

Russell, Bertrand (1959) Common Sense and Nuclear Warfare. London and New York: Routledge.

Russell, Bertrand (1961) 'The Battle of the Experts', The New Republic, 3 April, 17-18.

Sylvest, Casper (2009) 'Det britiske blik mod Tyskland. Transnationale dynamikker i national historiekultur, ca. 1850-1918', in Anne Magnussen, Klaus Petersen, Niels Arne Sørensen og Sissel Bjerrum Fossat (eds), Transnationale Historier (Odense: University of Southern Denmark Press, 2009), pp. 129-45.

Sylvest, Casper (2014) 'Russell's Realist Radicalism', International History Review, 36, DOI: 10.1080/07075332.2014.897249.

Thorpe, Charles (2004) 'Violence and the Scientific Vocation', Theory, Culture \& Society, 21, 59-84.

Wittner, Lawrence S. (2009) Confronting the Bomb: A Short History of the World Nuclear Disarmament Movement. Stanford: Stanford University Press.

\section{Noter}

* Forskningen, der ligger til grund for denne artikel, er finansieret af Det Fri Forskningsråd (FSE) som led i et projekt om „Globality and Planetary Security“ (GAPS). Vi vil gerne takke Johannes Lang, redaktørerne samt de anonyme bedømmere for deres nyttige kommentar på tidligere versioner af artiklen.
1. Man kan med fordel tale om to revolutioner snarere end én - eller i hvert fald en revolution i to faser. En første fase centreres omkring atomalderens første år, der kendetegnedes ved en meget aktiv deltagelse i den offentlige debat af naturvidenskabelige forskere bag udviklingen af atombomben. Den anden fase, centreret omkring perioden fra brintbombens opfindelse i de tidlige 1950'ere til den højspændte Kolde Krigs klimaks under Cuba-krisen ti år senere, er mindst lige så interessant i forhold til spørgsmålet om forholdet mellem viden og politik, men desværre også mindre indgående studeret i historisk og samfundsvidenskabelig forskning. Vi fokuserer her på centrale aspekter af forholdet mellem viden og politik, men den Kolde Krig var naturligvis kulturproducerende på en række yderligere områder ( $f_{x} \mathrm{k} ø n$, miljø, individuel frihed, psykologi, og økonomi).

2. Oppenheimer selv indtog en mellemposition, og gav først for alvor udtryk for sine moralske kvaler i forbindelse med udviklingen af brintbomben.

3. 'In evaluating advice from a specialist which departs from the area of his specialty, Government officials charged with the military posture of our country must also be certain that underlying any advice is a genuine conviction that this country cannot in the interest of security have less than the strongest possible offensive capabilities in a time of national danger.' Se Findings and Recommendations of the Personnel Security Board in the Matter of Dr. J. Robert Oppenheimer, UNITED STATES ATOMIC ENERGY COMMISSION, Washington, D.C., May 27, 1954 (http://avalon.law.yale. edu/20th_century/opp01.asp).

4. Pugwash organisationen opstod på baggrund af det såkaldt RussellEinstein manifest (1955) og har til formål at tilvejebringe videnskabelig viden om kernevåben og andre globale sikkerhedstrusler samt at arbejde for fredelig konfliktløsning. Organisationens første konference blev afholdt i 1957 i den canadiske landsby Pugwash. En lang række videnskabsfolk har siden deltaget i organisationens arbejde. Pugwash modtog Nobels Fredspris i 1995.

5. Selv om debatten i det store hele blev præget af større konformitet, er historien selvfølgelig mere kompliceret. På den ene side udfordrede drejningen mod ekspertise (og væk fra visdom) i 1950erne på længere sigt militariseringen af det politiske. Rollen som vidensproducerende ekspert var nemlig også med til at frembringe, skabe eller forandre viden, discipliner og problemfelter ( $\mathrm{fx} ø$ kologi, metereologi), der bidrog til tilvejebringelsen af de data og modeller, der udgør fundamentet for vores forståelse af globale klimaforandringer (Edwards, 2012; Hamblin, 2013; Masco, 2010). På den anden side var der selvfølgelig modtendenser. Udover de nukleare realister vi behandler nedenfor, kunne man fx nævne Barry Commoner, der forsøgte at gøre videnskab til genstand for offentlig debat (Egan, 2007). Generelt blev der dog i koalitionen bag styrkelsen af populærvidenskab lagt mere vægt på at styrke befolkningens forståelse for videnskabens bidrag til fremskridt og fred end på en analyse af videnskabelige frembringelsers positive og negative konsekvenser (Lewenstein, 1992).

6. Se fx en række fremtrædende samfundsvidenskabelige analyser af bomben i en særudgave af The Annals of the American Academy of Political and Social Science (1947).

7. Der var derfor brug for flere midler; ja ligefrem for et samfundsvidenskabeligt „Manhattan Project“ (Jacobs, 2010). Det var logisk og nødvendigt, hævdede Ogburn (1946, 267-8, 274), at bruge minimum et tilsvarende beløb på samfundsvidenskabelig forskning som der var brugt på bombens udvikling.

8. Brodies ideer grundlagde den såkaldte gyldne æra for strategisk tænkning i 1950'erne (Baldwin, 1995), og han forblev en central figur i bevægelsen, selvom han også senere udtrykte tvivl om den analysemodel han havde været med til at fostre. 
9. Selvom Ogburn oprindeligt (og i modsætning til Brodie) støttede naturvidenskabsmændenes ide om supranationalt samarbejde, beskæftigede han sig senere især med, hvordan man kunne sikre den amerikanske befolknings overlevelse i tilfældet af et atomangreb. Det var i tråd med hans grundlæggende idé om behovet for menneskelig tilpasning til teknologisk udvikling. Men det udviklede sig også til et skoleeksempel på social engineering, da Ogburn foreslog, at befolkninger og industrier skulle spredes ud over USA (horisontalt og vertikalt, dvs. underjordisk) for at minimere antallet af ofre i tilfælde af et angreb. Ogburn estimerede, at 200 amerikanske byer med en befolkning på over 50.000 kunne (og burde) omdannes til 1000 småbyer (Ogburn, 1946: 270-1).

10. Ball (1989). Der var naturligvis store forskelle mellem forskellige discipliner. For eksempler på nyere, indsigtsfulde analyser af moderniseringsteori, strategiske studier og antropologi se henholdsvis Gilman (2003), Kuklick (2006) og Mandler (2012). Samfundsvidenskabelige analyser baseret på økonomisk-rationelle antagelser fik et afgørende gennembrud under John F. Kennedy's præsidentpe- riode, hvor civile intellektuelle (såkaldte whiz kids, the best of the brightest) fra universiteter og tænketanke blev in-house eksperter og rådgivere, bl.a., men ikke kun på det militær-strategiske område.

11. De gjorde fx klart, hvordan kernevåbnenes farlighed også bestod $\mathrm{i}$, at de underminerede den traditionelle internationale politiks karakter og institutioner ( $\mathrm{fx}_{\mathrm{x}}$ diplomati), ligesom de kritiserede ideer om begrænset nuklear krig (der kan ses som et håbløst forsøg på at genvinde krigens politiske karakter). Bombens størrelse var dens problem, som Anders formulerede det: „Ihre Allmacht ist ihr Defekt" (Anders, 1956: 258).

12. Hannah Arendt, Günther Anders’ første ægtefælle, bidrog senere med denne indsigtsfulde analyse af den strategiske tænknings besnærende karakter: ' $[B]$ ecause of their inner consistency, they [strategic theories] have a hypnotic effect; they put to sleep our common sense, which is nothing else but our mental organ for perceiving, understanding and dealing with reality and factuality" (Arendt, 1969, 8). 